\title{
Upaya Guru dan Kepala Madrasah dalam Meningkatkan Daya Saing Madrasah
}

\author{
Siti Umayah \\ MI Ma'arif Seloprojo Ngablak Magelang \\ Email: Umayah@yahoo.com \\ DOI: $10.18326 /$ mudarrisa.v7i2.259-288
}

\begin{abstract}
Abstrak
Penelitian ini bertujuan untuk mengetahui strategi guru Sekolah Islam dan kepala sekolah untuk meningkatkan daya saing sekolah dan untuk menganalisis objektivitas strategi menuju sekolah berdaya saing. Peneliti menggunakan metode eksploratif deskriptif dalam melakukan penelitian ini dengan melakukan observasi dan wawancara. Objek penelitian ini adalah dua pesantren yang dipilih secara purposive; yaitu MTs N Ngablak dan MTs Ma'arif 3 Grabag Magelang. Hasil penelitian ini menunjukkan bahwa ada tujuh strategi yang digunakan oleh kepala sekolah Islam untuk meningkatkan daya saing sekolah. Tujuh strategi tersebut adalah efektifitas peran komite sekolah Islam, restrukturisasi organisasi sekolah, pengembangan kurikulum pendidikan (KTSP), meningkatkan profesi, sarana dan prasarana pendidik, melaksanakan berbagai program pembelajaran, dan memberikan jam tambahan untuk les pelajaran. Sementara itu, akurasi objektivitas strategi untuk meningkatkan daya saing menunjukkan enam sumber yang memiliki daya dukung tinggi yang telah terbukti berhasil yaitu upaya meningkatkan profesionalisme guru dan karyawan, meningkatkan manajemen dan administrasi sekolah dengan kerja tim, kepemimpinan
\end{abstract}


yang kuat dan visioner serta tim yang solid, ketersediaan sumber belajar, meningkatkan pelaksanaan kurikulum, peningkatan ketersediaan dan infrastruktur pemeliharaan sekolah dan meningkatkan akuntabilitas sekolah.

This study is intended to find out the Islamic School's teachers and headmasters strategies to improve school competitiveness and to analyze the objectivity of the strategies toward schools' competitiveness. The researcher used Descriptive explorative methods in conducting this research by doing observation and interview. The objects of this research are two Islamic School chosen purposively; they are MTs N Ngablak and MTs Ma'arif 3 Grabag, Magelang. The result of this research shows that there are seven strategies used by Islamic Schools' headmaster to improve schools' competitiveness. They are effectiveness of Islamic School committee role, restructuring school organization, developing the education curriculum (KTSP), improving the educators' profession, meeting of facilities and infrastructure, implementing various learning programs, and giving extra hour for tutoring lessons. Meanwhile, the accuracy of objectivity of strategies to improve competitiveness shows six resources which has a high carrying capacity that has been successfully proven, they are; continuously effort of improving teachers and employees professionalism, improving management and school's administration with a strong and visionary leadership team work and solid, the availability of learning resources, enhancing the implementation of successful curriculum, availability improvement and maintenance school's infrastructures and improving schools' accountability.

Kata kunci: guru, kepala sekolah islam, daya saing.

\section{Pendahuluan}

Dalam era persaingan yang berkembang amat ketat, setiap lembaga dipaksa berhadapan dengan lembaga lainya dalam arena persaingan. Semua lembaga umumnya berkeinginan untuk dapat tampil yang terbaik guna menarik perhatian pasar. Dalam arena persaingan, 
boleh jadi setiap lembaga melakukan berbagai hal guna memenangkan persaingan. Mungkin ada yang menggunakan cara-cara yang kotor dan ada pula yang menggunakan cara-cara yang baik dalam memenangkan persaingannya. Mereka yang tampil dengan pola yang baik, ada yang memperkokoh Sumber Daya Manusianya (SDM), ada yang memperkuat bidang fasilitas, dana, atau yang lainnya. Di sini penulis akan membahas upaya Guru dan Kepala Madrasah untuk meningkatkan daya saing madrasah.

Untuk memenangkan persaingan, para penyelenggara pendidikan harus memiliki spirit selalu berada di depan perubahan dengan jaminan bahwa mereka akan sampai lebih dulu digaris finish, karena persaingan adalah adu cepat untuk mencapai garis finish (Mulyasana, 2012: 184).

Di Indonesia, lembaga pendidikan sebagai wadah bagi peningkatan mutu sumber daya manusia memiliki banyak ragam. Di antaranya yang dapat ditemukan adalah madrasah. Dalam sejarahnya menurut Sutrisno (2005:73), maksud didirikannya madrasah pada hakekatnya adalah untuk mengumpulkan kelebihan yang ada pada pesantren dan sekolah umum sekaligus pada satu lembaga bernama madrasah. Sebagaimana diketahui, madrasah memang memiliki kelebihan dalam ilmu-ilmu agama dan sekolah dan sekolah memiliki kelebihan dalam ilmu-ilmu umum. Itulah sebabnya, madrasah diharapkan mampu mensinergikan kedua kelebihan yang dapat membuatnya berstandar mutu sejajar atau bahkan lebih tinggi daripada sekolah umum . 
Baidhawy (2007: 1-17) berpendapat perubahan-perubahan dalam lembaga pendidikan Islam pasca reformasi lebih melukiskan pola kultural perubahan sosial. Perubahan ini dimulai dari upaya penyadaran melalui dua tingkatan: pada tingkat individu dilakukan dengan mengubah cara berpikir masyarakat secara individual, dan pada tingkatan kolektif penyadaran dilakukan dilakukan dengan perbahan perilaku sosial. Dua upaya penyadaran ini menempatkan agama (baca: Islam) sebagai kekuatan moral, intelektual dan inspirasional bagi perilaku individu dan kolektif.

Pendidikan merupakan proses untuk meningkatkan, memperbaiki, mengubah pengetahuan, ketrampilan dan sikap, serta tata laku seseorang atau kelompok dalam usaha untuk mencerdaskan kehidupan manusia melalui kegiatan bimbingan, pengajaran dan pelatihan. Proses pendidikan menunjukkan adanya aktivitas atau tindakan aktif dan interaksi dinamis yang dilakukan secara sadar dalam usaha untuk mencapai tujuan.

Saat ini, dunia pendidikan sedang diguncang oleh berbagai perubahan sesuai dengan tuntutan dan kebutuhan masyarakat, serta ditantang untuk dapat menjawab berbagai permasalahan local dan perubahan global yang terjadi begitu pesat. Perubahan dan permasalahan tersebut meliputi pasar bebas (free trade), tenaga kerja bebas (free labour), perkembangan informasi, serta perkembangan ilmu pengetahuan, teknologi, seni, dan budaya yang dahsyat. Bersamaan dengan itu, bangsa Indonesia dihadapkan pada fenomena yang dramatis, yakni rendahnya daya saing sebagai salah satu indicator bahwa pendidikan belum sepenuhnya menghasilkan sumber daya manusia 
Upaya Guru dan Kepala Madrasah dalam Meningkatkan Daya Saing Madrasah (Siti Umayah)

(SDM) berkualitas. Ini merupakan tantangan agar seluruh komponen pemerhati pendidikan lebih meningkatkan kinerjanya. Upaya menciptakan sistem pendidikan yang bagus sebagai wahana untuk mewujudkan tujuan pendidikan dapat dilakukan dengan memperbaharui visi, misi, dan strategi pendidikan nasional serta mengimplementasikannya dalam lapangan.

Pengembangan sumber daya manusia dalam bidang pendidikan merupakan hal yang tidak bisa ditawar lagi. Hal ini sesuai dengan kebutuhan di lapangan yang menuntut pengelola pendiidkan agar dapat membuat perencanaan, pengorganisasian, melaksanakan, dan evaluasi pendidikan secara mandiri sebagaimana diamanatkan Undang-Undang Sistem Pendidikan Nasional No. 20 Tahun 2003 serta Peraturan Pemerintah No. 19 Tahun 2005 tentang Standar Nasional Pendidikan. Perundang-undangan tersebut menuntut penataan manajemen dalam berbagai jalur dan jenjang pendidikan serta mutu tenaga pendidik sesuai dengan standar pendidik dan tenaga kependidikan, sehingga tujuan masyarakat segera terwujud. Dalam studi keberhasilan kepala sekolah dalam memimpin lembaga sekolah menunjukkan bahwa kepala sekolah adalah seorang yang menentukan titik pusat dan irama suatu sekolah. Kepala sekolah selaku top leader mempunyai wewenang dan kekuasaan serta strategi kepemimpinan yang efektif untuk mengatur dan mengembangkan bawahannya secara professional. Lebih jauh studi tersebut menyimpulkan bahwa keberhasilan sekolah adalah keberhasilan kepala sekolah. Dalam hal ini kepala sekolah merupakan salah satu 
komponen pendidikan yang paling berperan dalam meningkatkan kualitas (mutu) pendidikan.

Berbagai upaya harus dipikirkan dan dilaksanakan oleh kepala sekolah guna meningkatkan kualitas pendidikan. Banyak faktor yang dapat mempengaruhi mutu pendidikan. Namun karena bidang pendidikan sangat luas cakupannya, maka perlu pembatasan pendidikan di sekolah. Ada banyak faktor yang dapat menentukan kualitas pendidikan dalam usaha pengembangan sumber daya manusia.

Untuk mendukung kemajuan sekolah juga tidak kalah pentingnya mengenai kompetensi professional guru, yaitu kemampuan dasar untuk menjalankan tugas secara professional. Guru harus mengetahui dan menguasai materi yang harus diajarkan, mempunyai kemampuan menganalisis materi yang diajarkan, dan menghubungkannya dengan konteks komponen-komponen secara keseluruhan, mengetahui dan dapat menerapkan berbagai pendekatan dan metode pembelajaran sesuai dengan kebutuhan, di samping mengetahui, dan terampil memanfaatkan berbagai media serta alat pembelajaran yang relevan dengan bahan ajar yang akan diajarkan.

Profesi guru telah diakui memiliki banyak kontribusi terhadap pembentukan sikap, perilaku, serta ketercapaian transfer of learning kepada para peserta didik baik secara individu maupun kelompok. Jasa para guru ini patut dihargai dengan segala konsekuensi peningkatan kesejahteraan dan taraf kehidupannya, karena mereka disamping merupakan tumpuan harapan bagi orang banyak, baik rakyat jelata 
maupun petinggi negara, juga tidak terbayangkan akan seperti apa masa depan generasi muda bangsa ini jika tanpa sentuhan profesionalitas guru.

Dengan dilandasi sebuah idealisme dan harapan yang besar akan terwujudnya sistem pendidikan di Madrasah yang mampu mengangkat derajat dan kualitas madrasah. Harapan itu akhirnya madrasah akan dapat sejajar dan mempunyai daya saing yang tinggi dengan lembaga pendidikan umum yang lain.

Perhatian penulis tefokus pada dua hal yaitu upaya guru dan kepala madrasah untuk meningkatkan daya saing madrasah dan analisa ketepatan dan objektivitas upaya guru dan kepala madrasah dalam meningkatkan daya saing madrasah.

Pendidikan Nasional di Indonesia masih banyak kelemahannya sehingga masih belum dapat mengangkat derajat dan kualitas sumber daya manusia untuk dapat bersaing dengan negara lain. Diantara kelemahan itu adalah aplikasi komitmen pemerintah dalam kebijakan pengalokasian anggaran pendidikan belunm tuntas, kurangnya kesejahteraan guru, kurangnya profesionalnya para pengelola pendidikan.

Guru merupakan suatu profesi yang berarti suatu jabatan yang memerlukan keahlian khusus sebagai guru dan tidak dapat dilakukan oleh sembarang orang di luar bidang pendidikan . Profesionalisme guru merupakan suatu keharusan dalam mewujudkan madrasah yang berkualitas . Kualitas guru sangat berdampak terhadap kualitas madrasah. Profesionalisme juga selalu dihubungkan dengan aspek kesejahteraan. 
Krisis pendidikan yang terjadi di Indonesia salah satu penyebabnya diantaranya adalah kurang profesionalnya Kepala madrasah atau sekolah. Kepala Madrasah belum mampu menunjukkan kinerja (work performance) yang memadai, belum mempunyai kemampuan yang inovatif untuk membawa madrasah yang dipimpin menjadi sebuah institusi yang dinamis dan mampu menjawab kebutuhan masyarakat. Untuk itu diperlukan figur kepala madrasah yang inovatif dan kreatif serta mempunyai komitmen yang kuat untuk memajukan lembaga pendidikan yang dipimpinnya.

Madrasah masih menyimpan sejumlah persoalan yang patut menjadi perhatian. Pertama, lemahnya manajemen dan leadership. Kondisi administrasi ,kepemimpin kepala sekolah, kinerja guru, staf dan seterusnya masih memprihatinkan. Kedua, partisipasi masyarakat terhadap Madrasah masih rendah. Kalaupun masuk madrasah itupun ,itu dilakukan karena putra putrinya tidak tertampung di sekolah.

Karena itulah agar madrasah dapat mengejar ketertinggalannya, perlu di upayakan langkah-langkah strategis atau kiat-kiat khusus yang dilakukan oleh pengelola madrasah yang dibantu oleh semua pihak, di antaranya dewan guru, karyawan, pemerintah pusat dan daerah, lembaga-lembaga swasta dan juga stakeholders untuk sama-sama berupaya memperbaiki dan meningkatkan mutu dan daya saing madrasah.

Dalam merumuskan strategi atau kiat -kiat peningkatan mutu madrasah, Yahya Umar dalam bukunya (Tobroni, 2007:5-7): mengibaratkan madrasah sebagai mesin, maka ada tiga hal yang 
selayaknya dilakukan oleh para perumus strategi, yaitu menyehatkan mesin, mengurangi beban dan merubah beban menjadi energi .

Pertama, menyehatkan mesin. Madrasah yang sehat adalah yang memiliki budaya organisasi yang positif dan proses organisasi yang efektif. Dalam mewujudkan budaya madrasah yang baru diperlukan konsolidasi idiil berupa reaktualisasi dokrin-doktrin agama yang selama ini mengalami pendangkalan, pembelokan dan penyempitan makna. Konsep tentang ikhlas, jihad, dan amal shaleh perlu direaktualisasikan maknanya dan dijadikan core Values dalam penyelenggaraan pendidikan madrasah.

Kedua, kurangi beban. Madrasah memang sarat beban , apabila dilihat dari missi, muatan kurikulum , beben -beban sosial dan budaya juga politik. Karena itulah penyelenggaraan kurikulum madrasah perlu diformat lagi sedemikian rupa agar tidak terpaku pada formalitas yang padat jam tetapi tidak padat misi dan isi. Karena pada akhirnya orientasi pendidikan tidak akan lagi pada " having" tetapi "being", bukan "schooling" tetapi " learning", dan bukan " transfer of knowledge" tetapi membangun jiwa melalui " transfer of values" lewat keteladanan.

Ketiga, merubah beban menjadi energi. Pengelola madrasah baik pimpinan maupun gurunya haruslah menjadi orang yang cerdik, teliti dan kreatif. Pemimpin madrasah tidak sepatutnya hanya berperan sebagai administrator, "pilot" atau "masinis" yang hanya menjalankan tugas sesuai dengan ketentuan, melainkan harus diibaratkan seorang "entrepeneur"yang senatiasa berupaya menciptakan nilai tambah dengan cara mendayagunakan kekuatan untuk menutupi kelemahan, 
mencari dan memanfaatkan peluang yang ada, dan merubah ancaman menjadi tantangan (analisis swot) .Intinya, cara merubah beban menjadi energi adalah dengan cara berfikir dan berjiwa besar, positif, kreatif dan tidak kenal menyerah.

Dalam era globalisasi yang ditandai dengan persaingan kualitas atau mutu, menuntut semua pihak dalam berbagai bidang sektor pembangunan untuk senantiasa meningkatkan kompetensinya (profesionalismenya). Profesionalisme adalah ide, aliran atau pendapat suatu profesi yang harus dilaksanakan dengan professional dengan mengacu kepada norma-norma profesionalisme.

Dalam pengertian profesionalisme tersirat adanya suatu keharusan memiliki kemampuan agar profesi guru berfungsi dengan sebaikbaiknya. Dalam hal ini pekerjaan professional berbeda dengan pekerjaan lain karena mempunyai fungsi sosial, yakni pengabdian kepada masyarakat. Kemampuan untuk mengembangkan dan mendemonstrasikan perilaku bukan sekedar mempelajari keterampilanketerampilan tertentu melainkan penggabungan dan aplikasi suatu keterampilan.

\section{Upaya Peningkatan Daya Saing Madrasah}

Secara bahasa, Peningkatan daya saing terdiri dari kata peningkatan dan daya saing. Kata peningkatan memiliki arti proses, cara, atau perbuatan meningkatkan (usaha, kegiatan, dan lain-lain) (KBBI, 1998: 951). Sedangkan daya saing di sini merupakan kekuatan 
untuk berusaha menjadi lebih dari yang lain atau lebih unggul dalam segala hal.

Dalam Permendiknas No 41 Tahun 2007 Tentang standar proses, dinyatakan bahwa daya saing adalah kemampuan untuk menunjukkan hasil yang lebih baik, lebih cepat dan lebih bermakna. Kemampuan tersebut meliputi : Kemampuan memperkokoh posisi pasar, kemampuan menghubungkan dengan lingkungan, kemampuan meningkatkan kinerja tanpa henti, kemampuan menegakkan posisi yang menguntungkan. Daya saing adalah potensi atau kemampuan lembaga untuk mengungguli persaingan yaitu keunggulan disatu bidang yang tidak di miliki oleh pihak lain. Daya saing madrasah dalam konteks era kekinian merupakan suatu hal yang mutlak. Daya saing ini berkorelasi dengan mutu madrasah, semakin berkualitas dan professional pengelolaan madrasah maka ia akan semakin kompetitif.

\section{Urgensi Peningkatan Mutu dan Daya saing Madrasah}

Penyelenggaraan pendidikan yang efektif dan efisien dari sebuah madrasah seharusnya mengacu kepada kepentingan masyarakat yang kompleks dan terus berubah dari setiap masa.Karena itulah,kapabilitas dan kompetensi kerja yang dimiliki oleh para lulusan madrasah harusnya memiliki kesesuaian dengan kebutuhan masyarakat:pengguna jasa lulusan .Diperlukanya perencanaan yang harmonis antara"manpower planning"dengan"planning for education" menurut William J. Platt dapat meningkatkan mutu dan relevansi pendidikan (Rukmana, 2006: 11). Salah satu faktor yang menyebabkan banyaknya "educated unemployed" 
(berpendidikan yang menganggur) di Indonesia antara lain disebabkan mutu manajemen pendidikan yang tidak normal. Padahal ,untuk mempertahankan mutu menejemen, sebuah madrasah minimal harus memiliki dua elemen penting,yakni sistem dan mutu tenaga pengajar (Rukmana,2006: 11-12).

Dikarenakan sifat kelenturan mutu yang bisa digunakan tidak hanya dalam dunia industri namun juga sosial seperti pendidikan,mutu memiliki sisi-sisi fokus yang bisa diteliti.Karena itulah, mutu memiliki beragam pengertian tergantung dari sisi mana mutu itu dilihat.

"Mutu berasal dari bahasa latin, qualis, yang artinya what kind of.Mutu menurut Deming ialah kesesuaian dengan kebutuhan pasar. Mutu menurut Juran ialah kecocokan dengan produk. Mutu menurut Crosby ialah kesesuaian dengan yang diisyaratkan. Mutu menurut WestBurnham ialah ukuran relatif suatu produk atas jasa sesuai dengan setandar mutu desain. Mutu menurut Sallis ialah suatu konsep yang selain sulit didefinisikan,mudah lepas dan sulit dipegang, mutu juga merupakan konsep yang absolut dan relatif'(Sallis, 2006: 46).

Daya saing dalam pendidikan bukanlah sesuatu yang berdiri sendiri, namun merupakan satu kesatuan yang saling berhubungan dan terkait.Karena itulah jika ingin mengetahui pencapaian mutu dan daya saing dalam suatu institusi , mutu haruslah dikaitkan dengan input, proses, dan output.

Input pendidikan dikatakan bermutu jika siap berproses. Proses pendidikan dikatakan bermutu apabila mampu menciptakan suasana yang PAIKEM (Pembelajaran yang Aktif , Inovatif, Kreatif dan 
Menyenangkan). Sedang output dinyatakan bermutu jika hasil akademik dan non akademik siswa tinggi. Bermutu dan berdaya saing bermanfaat bagi dunia pendidikan, karena: 1) meningkatkan pertanggungjawaban (akuntabilitas) sekolah kepada masyarakat dan pemerintah; 2) menjamin mutu lulusannya; 3) bekerja lebih profesional; dan 4) meningkatkan persaingan yang sehat. Keberhasilan madrasah dalam meningkatkan mutu dan daya saing pendidikannya tidak hanya dilihat dari nilai ujian akhir yang diperoleh para lulusannya, namun dapat juga dilihat dari faktor-faktor lain yang ada dilingkungan madrasah.

Efektivitas proses pembelajaran bukan sekedar transfer pengetahuan (transfer of knowledge) atau mengingat dan mengungsi pengetahuan tentang apa yang diajarkan, melainkan lebih menekankan kepada internalisasi mengembangkan aspek-aspek kognitif, afektif, psikomotorik dan kemandirian.

Kepemimpinan kepala madrasah yang kuat, merupakan salah satu faktor yang dapat mendorong madrasah untuk mewujudkan visi, misi, tujuan dan sasaran melalui program yang dilaksanakan secara berencana, bertahap, kreativitas, inovasi, efektif, dan mempunyai kemempuan manajerial.

Pengelolaan tenaga kependidikan yang efektif; guru merupakan salah satu faktor yang strategis pada satu madrasah, dituntut mempunyai kreativitas dan keuletan dalam mengelola proses pembelajaran, mampu merespon isu-isu pendidikan sehingga madrasah itu mampu bersaing dalam hal mutu. 
Madrasah memiliki budaya mutu. Semua warga madrasah dengan didasari profesionalisme di bidangnya masing-masing sesuai dengan fungsi dan perannya. Madrasah memiliki team work yang kompak, cerdas dan dinamis, kebersamaan merupakan karakteristik madrasah, karena out put pendidikan hasil kolektif warga madrasah bukan hasil individual yang menjadi persyaratan penting untuk memperoleh mutu yang kompetitif.

Madrasah memiliki kemandirian; yaitu madrasah mempunyai kemampuan dan kesanggupan kerja secara maksimal dengan tidak selalu bergantung pada petunjuk atasan dan harus mempunyai sumber daya potensial dan berkompeten dibidangnya masing-masing. Adapun faktor yang meningkatkan kemandirian madrasah, diantaranya partisipasi warga madrasah dan masyarakat, madrasah memiliki transparansi dalam pengelolaan, madrasah memiliki kemauan perubahan, madrasah melakukan evaluasi perbaikan yang berkelanjutan, madrasah memiliki akuntabilitas (Sagala, 2000: 171-172). Faktor-faktor tersebut dibutuhkan dalam upaya peningkatan kemandirian madrasah, sehingga segala permasalahan dapat segera dicarikan solusinya dengan melibatkan pihakpihak yang berkepentingan.

\section{Upaya Kepala Madrasah dalam Meningkatkan Daya Saing}

Mengaplikasikan konsep Pengelolaan Mutu Terpadu (PMT) atau Total Quality Management (TQM). PMT/TQM merupakan pendekatan dalam menjalankan suatu unit usaha untuk mengoptimalkan daya saing organisasi melalui prakarsa perbaikan terus menerus atas produk, jasa, 
manusia, proses kerja, dan lingkungannya. Powell dalam Sudarwan (2002: 119) mengatakan: TQM is an integrated management philosophy and set of practicesthat emphasizes, among other things, continuous improvement, meeting customer's requirements, reducing rework, longrange thinking, increased employee involvement and team work, process redesign, competitive benchmarking, team-based problem solving, constant measurement of results, and closers relationship with supplier.

Pendapat di atas menggariskan bahwa PMT/TQM merupakan upaya untuk perbaikan terus- menerus dalam rangka untuk memenuhi kebutuhan kostumer, baik dalam baik dalam produk barang maupun jasa.Ini berarti bahwa organisasi harus mampu melakukan sebuah mekanisme perubahan kultur, dari kultur tradisional ke budaya mutu. Perubahan itu mencakup empat komponen fokus, yaitu: plan, organize, control, communication. (Sudarwan, 2002: 120)

Jadi, bahwa aplikasi PMT/TQM didasarkan atas sepuluh kaidah, yaitu fokus pada pelanggan, obsesi terhadap kualitas, pendekatan ilmiah, komitmen jangka panjang, kerja sama tim, perbaikan kinerja sistem berkelanjutansecara berkelanjutan, diklat dan pengembangan, kebebasan terkendali, kesatuan tujuan, serta keterlibatan dan pemberdayaan karyawan secara optimal.

\section{Peningkatan Hubungan Kerjasama Sekolah dengan Masyarakat}

Dalam hal ini kepemimpinan kepala madrasah mempunyai peranan menentukan sebagai suatu kekuatan atau kewibawaan (power) di dalam menghimpun dan menggerakkan segala sember daya di dalam 
kerja sama dengan masyarakat pendidikan yang lebih luas, serta untuk memperoleh berbagai dukungan informasi berbagai lembaga dan dukungan politis dari segenap jajaran aparat pendidikan (Wahjosumidjo, 2002: 332).

Pengaruh masyarakat terhadap sekolah sebagai lembaga sosial, terasa amat kuat, dan berpengaruh pula kepada para individu-individu yang ada dalam lingku ngan sekolah. Hasil penelitian menunjukkan, betapa penting dan perlunya program sekolah selalu menghayati adanya hubungan kerja sama antara sekolah dengan masyarakat. Masyarakat yang kompleks, yang terdiri dari kelompok-kelompok kecil dengan ciriciri kolektif yang dimilikinya, di mana sekolah itu berada, adakalanya kebijaksanaan sekolah,seperti; sasaran, tujuan, kurikulum, program dan sebagainya.

Oleh sebab itu perlu dipertimbangkan betul-betul, dalam memperbaiki dan mempertimbangkan hubungan kerja sama antara sekolah dengan masyarakat, yaitu dengan melibatkan orang tua, dan masyarakat serta isu-isu yang timbul dan bagaimana menyelesaikan isuisu tersebut.

Seorang kepala madrasah merupakan mata rantai penting di antara hubungan sekolah setempat dengan masyarakat yang lebih luas. Oleh sebab itu apabila proses mengajar dan belajar akan ditingkatkan, maka dukungan intelektual, teknis dan material harus dimanfaatkan secara tepat. Demikian pula hubungan dengan masyarakat yang memberikan dukungan dalam pengembangan program perbaikan sekolah, perlu diusahakan secara terus menerus. 


\section{Upaya guru dalam meningkatkan daya saing madrasah}

Dalam usaha peningkatan mutu pendidikan dan daya saing madrasah, terdapat dua hal utama yang menjadi kunci daya saing suatu madrasah, yaitu perbaikan mutu guru dan proses pembaruan administrasi pendidikan. Perbaikan mutu guru hendaknya prioritas utama, baik dalam menentukan kebijakan maupun dalam pelaksanaannya. Diantaranya adalah dengan mengadakan jaringan kerja guru, baik yang satu sekolah, satu bidang studi, maupun lintas bidang studi yang menjalin komunikasi (mengadakan pertemuan secara rutin) satu sama lain. Sehingga dengan kegiatan itu guru dapat bersifat proaktif untuk menemukan cara-cara untuk mengembangkan diri sebagai profesional.

Pembaruan dalam bidang administrasi pendidikan merupakan penerapan cara-cara baru dan kreatif dalam seleksi, aktif, inovatif, efektif, organisasi, dan penggunaan sumber-sumber manusia dan material, yang diharapkan meningkatkan mutu proses pengelolaan pendidikan dan hasil-hasilnya secara lebih berdaya guna dan berdaya saing (Sudarwan, 2002: 160).

Citra guru di masyarakat atau di negara kita berubah dari waktu ke waktu. Perubahan citra guru tersebut dipengaruhi oleh perubahan aspirasi (penilaian serta penghargaan), unjuk kerja para guru yang telah berkarya (performance), dan adanya perubahan persyaratan jabatan guru sebagai dampak kemajuan ilmu serta teknologi/era profesionalisasi dan spesialisasi (Samana, 1994: 13).

Agar mutu dan daya saing pendidikan tetap terjaga dan proses peningkatan mutu tetap terkontrol maka harus ada standar yang dijadikan 
sebagai acuan/pedoman sebagai indikator evaluasi keberhasilan peningkatan mutu tersebut. Pemikiran ini telah mendorong munculnya pendekatan baru,yakni pengelolaan peningkatan mutu daya saing pendidikan yang dikenal dengan Manajemen Peningkatan Mutu Berbasis Madrasah (MPMBM).

Manajemen Peningkatan Mutu Berbasis Madrasah (MPMBM) merupakan salah satu bentuk desentralisasi pendidikan yang dipilih dengan tujuan untuk memandirikan sekolah dan meningkatkan mutu pendidikan. Kebijakan ini diimplementasikan dengan menerapkan manajemen yang transparan dan dengan melibatkan pihak-pihak yang berkepentingan dengan pendidikan. Dalam implementasinya, kebijakan MPMBM memiliki strategi yang berbeda dimasing-masing madrasah sebab MPMBM menerapkan pendekatan "idiograpik” (membolehkan adanya keberbagaian cara pelaksanaannya).

\section{Tinjauan Mengenai Strategi dalam Manajemen Madrasah}

Pada dasarnya, istilah strategi dapat dirumuskan sebagai suat tindakan penyesuaian untuk mengadakan reaksi terhadap situasi lingkungan tertentu (baru dan khas) yang dapat dianggap penting, dimana tindakan penyesuaian tersebut dilakukan secara sadar berdasarkan pertimbangan yang wajar (Afif, 1984: 9). Gaffar (2014:14) mengartikan bahwa strategi adalah rencana yang menngandung cara komprehensif dan integratif yang dapat dijadikan pegangan untuk bekerja , berjuang dan berbuat guna memenangkan kompetisi. Strategi merupakan instrumen manajemen yang ampuh dan tidak dapat dihindari, tidak hanya 
untuk survival dan memenangkan persaingan, namun juga untuk tumbuh dan berkembang.

Secara umum ada sembilan langkah menyusun startegi dalam meningkatkan daya saing sebuah lembaga pendidikan memformulasikan sasaran, mengidentifikasikan tujuan dan strategi umum, menganalisa lingkungan, menganalisa sumber kekuatan dan kelemahan organisasi, mengidentifikasi peluang dan ancaman organisasi, menganalisa perbedaan, menetukan besarnya perubahan yang dikehendak dalam strategi umum, pengambilan keputusan yang meliputi mengembangkan alternatif, mengevaluasi alternatif, menyeleksi alternative, implementasi strategi, dan mengukur dan mengontrol kemajuan yang telah tercapai (Mulyasana, 2012: 239).

\section{Metode Penelitian}

Penelitian ini menggunakan pendekatan kualitatif yang lebih menekankan analisisnya pada proses penyimpulan, induktif serta pada analisis terhadap dinamika hubungan antar fenomena yang dicermati, dengan menggunakan logika ilmiyah (Azwar,1999:8).

Penelitian ini diharapkan dapat menemukan sekaligus mendeskripsikan data secara menyeluruh dan utuh mengenai Upaya atau Strategi Peningkatan Daya Saing Madrasah, pada Madrasah Tsanawiyah Negeri ( MTsN ) Ngablak dan MTs Ma'arif 3 Grabag Kabupaten Magelang. Menurut Suharsini, ada tiga macam pendekatan yang termasuk ke dalam penelitian deskriptif, yaitu penelitian kasus atau 
studi kasus, penelitian kausal komparatif dan penelitian korelasi (Arikunto,1998:247) .

Dalam penelitian ini menggunakan teknik pengumpulan data sebagai berikut, yaitu observasi, wawancara, dan studi dokumentasi. Observasi, teknik ini digunakan dengan tujuan untuk mengetahui apa saja upaya guru dan kepala madrasah dalam meningkatkan daya saing madrasah. Wawancara, pertimbangan di gunakan teknik ini adalah untuk memperoleh data dari sumbernya secara langsung dengan berbagai pihak yang terlibat langsung di madrasah. Studi dokumentasi, teknik ini dipergunakan untuk memperoleh data yang berkaitan dengan fokus penelitian. Pengumpulan data dilakukan dengan menyelidiki bendabenda tertlis seperti buku kurikulum, struktur organisasi, data-data pendindingan dan dokumen pendukung lainnya.

Untuk menetapkan keabsahan data diperlukan teknik pemeriksaan data. Pelaksanaan teknik pemeriksaan data didasarkan pada derajat kepercayaan (kredibilitas). Derajat kepercyaan ini berfungsi untuk : melaksanakan inkuiri sedemikian rupa sehingga tingkat kepercayaan penemuannya dapat dicapai dan untuk mempertunjukkan derajat kepercayaan hasil-hasil penemuan dengan jalan pembuktian oleh peneliti pada kenyataan ganda yang sedang diteliti (Moleong,1998:324).

Untuk menganalisa data, penulis menggunakan analisis data deskriptif eksploratif kualitatif dan analisis komparatif. Analisis data deskriptif kualitatif dengan langkah: reduksi data, display data, mengambil kesimpulan. Analisis data deskriptif komparatif dengan membandingkan hasil temuan peneliti. 
Upaya Guru dan Kepala Madrasah dalam Meningkatkan Daya Saing Madrasah (Siti Umayah)

\section{Pembahasan}

Dari hasil penelitian di MTsN Ngablak Kab. Magelang, dapat diketahui bahwa Kepala Madrasah selain sebagai pemimpin bagi madrasah yang dipimpinnya, juga berperan sebagai agent of change. Karenanya, kepala madrasah harus memiliki pemahaman yang baik tentang segala hal madrasahnya. Madrasah juga harus memiliki visi masa depan yang jelas agar rencana peningkatan mutu dan daya saing madrasah dapat terus dilakukan secara bertahap.

Upaya/Strategi Kepala Madrasah Tsanawiyah Negeri Ngablak dalam meningkatkan mutu dan daya saing madrasah antara lain pertama, membuka kelas unggulan dari setiap tingkat ( Rombongan belajaran) diambil satu kelas yang diunggulkan dengan menunjuk guru mapel Ujian Nasional dan Mapel UAMBN (Ujian Akhir Berstandar Nasional) untuk mengelola dengan baik dengan memberi pelayanan khusus yang berbeda dengan yang reguler. Kedua, memberikan perhatian yang lebih khusus kepada siswa yang berprestasi dengan diberi pelatihan tambahan materi pelajaran agar dapat berkompetisi dengan madrasah / sekolah lain. Ketiga, menambah jam pelajaran dengan mengadakan les baik siswa reguler maupun yang unggulan. Keempat, pendekatan dengan madrasahmadrasah ibtidaiyah sekitar MTsN Ngablak dengan memberikan brosur pendaftaran siswa baru, mengadakan kerja sama dalam peringatan hari besar Islam dll. Kelima, mengadakan promosi dengan memberikan brosur-brosur ke Madrasah Ibtidaiyah-Madrasah Ibtidaiyah atau Sekolah Dasar di sekitar wilayah kecamatan Ngablak. 
Dari hasil wawancara di atas kekuatan yang dimiliki MTs Negeri Ngablak dapat dipolakan menjadi tiga bagian besar yaitu mempunyai kekuatan di faktor sarana dan prasarana (gedung, fasilitas multi media dan adanya software Speedy), faktor peserta didik (adanya penigkatan jumlah siswa-siswi yang mendaftar di MTs Negeri dalam setiap tahunnya), dan faktor madrasah sendiri yang mengawal adanya pembelajaran berbasis multimedia dibanding madrasah lainnya di sekitar kecamatan Ngablak.

Adapun hasil dari penelitian di MTs Ma'arif 3 ini adalah Upaya Guru dan Kepala Madrasah dalam meningkatkan daya saing madrasah dengan menerapkan implementasi MPMBM sudah dilaksanakan dengan baik dengan melaksanakan langkah-langkah: 1) implementasi perencanaan (analisis situasi, merumuskan tujuan, analisis SWOT dan alternatif pemecahan masalah); 2) peningkatan mutu pendidikan dengan menyusun dan melaksanakan program; 3) implementasi monitoring dan evaluasi yang dilaksanakan secara berkesinambungan.

Strategi yang digunakan Kepala Madrasah sebagai upaya peningkatan mutu dan daya saing pendidikan yang lain adalah dengan mengefektifkan peran komite madrasah dan merombak organisasi madrasah, pengembangan kurikulum tingkatsatuan pendidikan (KTSP), peningkatan keprofesionalan SDM (tenaga pendidik), pemenuhan sarana dan prasarana, pelaksanaan berbagai programpembelajaran, menambah jam pelajaran dengan les diwaktu setelah jam pelajaran selesai.

Dampak MPMBM terhadap prestasi siswa cukup baik dengan meningkatnya prestasi akademik dan non akademik. Sedangkan dampak 
MPMBM dengan minat masyarakat terhadap madrasah semakin meningkat hal ini disebabkan ka|renamadrasah selalu mengikutsertakan komite dalam penyelenggaraan pendidikan, kinerja dari manajemen humas yang efektif di samping faktor gedung yang bagus,guru yang profesional dan pendidikan agama yang bermutu. Dan dampaknya bagi guru, dengan penerapan MPMBM, guru MTs Ma’arif 3 Grabag merasa bangga terhadap madrasah. Hal ini lebih disebabkan karena: manajemen madrasah yang semakin baik, kerjasama madrasah dan komite yang kompak, prestasi siswa semakin meningkat .

Dalam hal ini, strategi peningkatan mutu dan daya saing madrasah MTs Ma'arif 3 Grabag dapat dianalisa melalui beberapa hal. Formulasi strategi peningkatan daya saing MTs Ma'arif 3 Grabag terdiri dari beberapa tahapan, yaitu: pertama, analisis Lingkungan Internal dan Eksternal. Kedua, hasil dari analisis lingkungan eksternal adalah sejumlah peluang (opportunities) yang harus dimanfaatkan dan ancaman (threat) yang harus dicegah atau dihindari. Ketiga, sedangkan analisis lingkungan internal terdiri dari penentu persepsi yang realistis atas segala kekuatan (strength) dan kelemahan (weakness) yang di miliki MTs Ma'arif 3 Grabag. Karenanya, madrasah ini harus mengambil manfaat dari kekuatannya secara optimal dan berusaha untuk mengatasi kelemahannya agar terhindar dari kerugian baik waktu maupun anggaran. 


\section{Tabel 1}

Analisis SWOT Untuk Strategi Peningkatan Mutu dan Daya Saing

\begin{tabular}{|c|c|}
\hline INTERNAL & EKSTERNAL \\
\hline Strenght (S)/Kekuatan & Opportunity $(\mathrm{O})$ / Peluang \\
\hline 1. Lokasi strategis, tenang dan nyaman & 1. Kebijakan pemerintah tentang MBS \\
\hline 2. Koordinasi dan pembagian tugas jelas & Kesempatan madrasah untuk meng \\
\hline 3. Etos kerja guru dan karyawan tinggi & ikuti berbagai perlombaan baik \\
\hline 4. Kerjasama tim terjaga & akademik maupun non akademik \\
\hline 5. Adanya budaya mutu yang islami & tingkat lokal, propinsi, maupun \\
\hline $\begin{array}{l}\text { 6. Kepemimpinan Kepala Madrasah } \\
\text { tegas, dan berpengalaman }\end{array}$ & nasional \\
\hline 7. PBM yang diselenggarakan variatif & $\begin{array}{l}\text { Menggunakan kekuatan untuk } \\
\text { menghindari ancaman }\end{array}$ \\
\hline Strategi SO & \\
\hline Menggunakan kekuatan untuk & Threat (Ancaman) \\
\hline memanfaatkan peluang & $\begin{array}{l}\text { 1. Menurunnya jumlah lulusan yang } \\
\text { menerskan ke SLTA }\end{array}$ \\
\hline Weakness ( W ) /Kelemahan & 2. Peran serta stake holders kurang \\
\hline $\begin{array}{l}\text { 1. Input siswa kurang bermutu dari segi } \\
\text { prestasi akademik }\end{array}$ & $\begin{array}{l}\text { 3. Situasi kondisi sosial, ekonomi dan } \\
\text { politik tidak stabil }\end{array}$ \\
\hline 2. Sarana dan prasarana kurang lengkap & \\
\hline $\begin{array}{l}\text { 3. Gurunya berijazah tidak sesuai } \\
\text { dengan mapel yang diampu }\end{array}$ & $\begin{array}{l}\text { Mengatasi kelemahan dengan } \\
\text { Menghindari ancaman }\end{array}$ \\
\hline $\begin{array}{l}\text { 4. Rendahnya dukungan orang tua siswa } \\
\text { terhadap KBM anaknya sehingga } \\
\text { banyak siswa yang tidak punya buku } \\
\text { pelajaran dn hanya mengandalkan } \\
\text { koleksi perpustakaan }\end{array}$ & \\
\hline $\begin{array}{l}\text { 5. Kurangnya koleksi buku } \\
\text { perpustakaan terutama buku pelajaran }\end{array}$ & \\
\hline $\begin{array}{l}\text { 6. Kurangnya biaya operasional } \\
\text { Pendidikan }\end{array}$ & \\
\hline $\begin{array}{l}\text { Strategi WO } \\
\text { Memperbaiki kelemahan dan mengambil } \\
\text { manfaat dari peluang }\end{array}$ & \\
\hline
\end{tabular}

Dalam menyikapi segala macam perubahan dan tantangan globalisasi, dapat dikatakan MTs Ma'arif 3 Grabag memiliki keberanian untuk terus melangkah maju mengejar ketertinggalannya dengan 
madrasah-madrasah lainnya. Peningkatan mutu dan daya saing madrasahnya pun terus menerus diupayakan, dan hal ini dapat dilihat dari wawancara dengan Bapak Aris Djawadir, selaku Kepala Madrasah MTs Ma'arif Grabag.

Upaya Peningkatan daya saing madrasahnya pun dilakukan seprti misalnya upaya merancang untuk menjadi madrasah unggulan walaupun salah satu input nya, yakni siswa disadari kurang bermutu oleh segenap warga MTS Ma'arif Grabag. Karenanya, diadakan les (penambahan jam pelajaran) tidak hanya ketika mau ujian saja .

\section{Upaya Guru dan Kepala Madrasah}

Penekanan akan objektivitas strategi peningkatan mutu MTsN Ngablak sangatlah penting bagi implementasi strateginya. Adapun upaya peningkatan daya saing madrasah ini disusun bukan atas dasar kehendak pribadi kepala madrasah saja, namun lebih merupakan kehendak bersama seluruh warga madrasah dalam mengakomodasi kebutuhan publik berdasarkan prinsip-prinsip objektifitas, ilmiah, dan sistematis. Tujuannya adalah terciptanya suatu sistem dan strategi manajemen madrasah yang niscaya dan pasti mampu meningkatkan mutu yang kompetitif dan menguntungkan.

Setelah didapatkan gambaran lingkungan internal dan eksternal yang dihadapinya, MTsN Ngablak mengetahui kondisi dasar lembaganya. Maka dalam menentukan strategi dan upaya, perlu memperhatikan berbagai hal, termasuk kemampuan SDM (seperti guru, kepala madrasah, dan pegawai) dan anggaran. Langkah-langkah perumusan strategi dalam manajemen madrasah dimulai dari penetapan 
Visi dan misi madrasah yang utuh dengan melibatkan masyarakat dan stakeholder madrasah, melakukan assesment madrasah untuk merespon perubahan, dan menetapkan arah maupan ssaran madrasah agar tercapai tujuan dan target yang ditentukan sebelumnya.

Berdasarkan uraian di atas dapat dilihat bahwa selain adanya upaya Madrasah untuk terus meningkatkan mutu dan daya saing pendidikannya, ternyata madrasah juga terus berupaya untuk mempertahankan setiap prestasi yang telah diraihnya. Karenanya, dalam penelitian ini ditemukan bahwa Upaya kepala Madrasah dan Guru dalam meningkatkan daya saing ini, baik di MTsN Ngablak MTs Ma'arif 3 Grabag pada akhirnya menghasilkan enam sumber daya madrasah yang mempunyai daya dukung tinggi yang telah terbukti memberikan keberhasilan bagi madrasah dalam melaksanakan upaya peningkatan mutu dan daya saing madrasah, yaitu: adaya upaya yang terus menerus akan peningkatan profesionalitas ketenagaan yang terdiri dari para guru dan karyawan, peningkatan manajemen dan administrasi madrasah dengan kepemimpinan yang kuat dan visioner juga team work yang solid, peningkatan ketersediaan sumber-sumber pembelajaran, peningkatan keberhasilan pelaksanaan kurikulum, peningkatan ketersediaan pengadaan dan perawatan sarana-prasarana, dan peningkatan akuntabilitas madrasah.

\section{Simpulan}

Upaya yang dilakukan guru dan kepala madrasah MTsN Ngablak dalam meningkatkan daya saing madrasah dimulai dengan menganalisa peningkatan mutu madrasahnya yang dilihat dari pendekatan sistem 
Upaya Guru dan Kepala Madrasah dalam Meningkatkan Daya Saing Madrasah (Siti Umayah)

(input, proses dan output). Dari input, penelitian ini mencoba melihat potensi atau modal dasar yang dimiliki MTsN Ngablak yaitu visi dan misi, tujuan dan sasaran, dan pengadaan siswa yang berkualitas.

Setelah menganalisa peningkatan mutu MTsN Ngablak melalui pendekatan sistem kemudian dilanjutkan dengan menganalisa proses pendidikan di MTsN Ngablak. Hasil yang didapatkan adalah: pertama, MTsN Ngablak menyiapkan inovasi kurikulum dalam rangka upaya menghadapi laju perkembangan zaman yang tidak hanya menuntut manusia Indonesia khususnya memiliki ilmu pengetahuan, namun juga memiliki keahlian dan profesi agar para lulusannya mampu menghadapi hidup secara mandiri dan kompeten serta berdaya saing.

Kedua, MTsN mengadakan mata pelajaran tambahan khas (muatan lokal), bahasa asing, pengembangan penalaran, dan bahasa jawa. Ketiga, program olahraga intrakurikuler diarahkan menjadi olahraga prestasi (ORPRES). Keempat, Kepala madrasah berupaya membuka kelas unggulan dari setiap tingkat ( rombongan belajar) serta menciptakan budaya unggul dan berprestasi pada siswa. Kelima, Pendidikan seni diorientasikan seni prestasi dengan tujuan sebagai sarana dakwah islami. Keenam, menyiapkan sistem atau pola pembinaan dan pendampingan siswa. Ketujuh, menyiapkan sarana dan fasilitas madrasah yang menunjang secara bertahap. Kedelapan, menciptakan suasana madrasah yang kondusif. Kesembilan, kepemimpinan dan kultur. Kesepuluh, manajemen, Kesebelas, sumber daya guru.

Adapun hasil dari penelitian di MTs Ma'arif 3 ini adalah Upaya Guru dan Kepala Madrasah dalam meningkatkan daya saing madrasah 
dengan menerapkan implementasi MPMBM sudah dilaksanakan dengan baik dengan melaksanakan langkah-langkah: 1) implementasi perencanaan (analisis situasi, merumuskan tujuan, analisis SWOT dan alternatif pemecahan masalah); 2) peningkatan mutu pendidikan dengan menyusun dan melaksanakan program; 3) implementasi monitoring dan evaluasi yang dilaksanakan secara berkesinambungan; 4) menyiapkan sistem atau pola pembinaan dan pendampingan siswa; 5) menyiapkan sarana dan fasilitas madrasah yang menunjang secara bertahap; 6) menciptakan suasana madrasah yang kondusif; dan 7) memperbaiki manajemen dan sumber daya guru.

Strategi yang digunakan kepala madrasah sebagai upaya peningkatan mutu dan daya saing pendidikan yang lain adalah dengan mengefektifkan peran komite madrasah dan merombak organisasi madrasah, pengembangan kurikulum tingkat satuan pendidikan (KTSP), peningkatan keprofesionalan SDM (tenaga pendidik), pemenuhan sarana dan prasarana, pelaksanaan berbagai program pembelajaran, menambah jam pelajaran dengan les diwaktu setelah jam pelajaran selesai.

\section{Daftar Pustaka}

Peraturan Pemerintah No. 19 Tahun 2005 tentang Standar Nasional Pendidikan

Afif, Faisal. 1984. Strategi Pemasaran ,Bandung: Angkasa.

Arikunto, Suharsimi. 2002. Prosedur Penelitian Pendekatan Praktek. Jakarta: Rineka Cipta.

Azwar, Syarifuddin .1999. Metode Penelitian. Yogyakarta: Pustaka. Baidhawy, Zakiyuddin. 2007. Transformasi Pendidikan Islam Pascareformasi: Sekolah Dasar Islam dengan sistem integrasi, Jurnal Penelitian Sosial Keagamaan, Infersi. 
Sallis, Edward. 2006. Total Quality Manajemen in Education ,terj, Yogyakarta: IRCISOD.

Samana, A. 1994. Profesionalisme Keguruan. Yogyakarta: Kanisius.

Gaffar, M.F. 2004. Pembaharuan Manajemen Perguruan Tinggi pada Era Globalisasi, Makalah Konvensi Nasional Pendidika Indonesia V, Surabaya: Fokus.

Moleong, L.J. 2000. Metodologi Penelitian Kualitatif. Bandung: PT Remaja Rosdakarya.

Mulyasana, Dedi. 2012. Pendidikan bermutu dan Berdaya Saing. Bandung: PT Remaja Rosdakarya .

Rukmana, Nana. 2006. Strategik Partnering for Educational Management. Bandung: Alfabeta.

Sagala, Syaiful. 2000. Administrasi Pendidikan Kontemporer. Bandung: Alfabeta.

Sudarwan, Danim. 2002. Inovasi Pendidikan, Bandung: Pustaka Setia.

Sutrisno. 2005. Pemberdayaaan Madrasah dalam Menghadapi Era Globalisasi. Salatiga: Jurnal PAI,Vol II No. 1.

Tobroni, 2007. Percepatan Peningkatan Mutu Madrasah. Diambil dari http://www.tobroni.blogspot.com. Diakses 17 Mei 2011 
Mudarrisa: Jurnal Kajian Pendidikan Islam, Vol. 7, No. 2, Desember 2015: 259-288 